\title{
Differential expression of genes in follicular cells of swines ${ }^{1}$
}

\section{Cristiana Libardi Miranda Furtadoㄹ, Priscila Vendramini Silva², Marta Fonseca Martins Guimarães $^{3}$, Nicola Vergara Lopes Serão², José Domingos Guimarães ${ }^{4}$, Simone Eliza Facioni Guimarães ${ }^{2}$}

\author{
${ }^{1}$ Apoio financeiro: CAPES, CNPq, FAPEMIG e FINEP. \\ ${ }^{2}$ Departamento de Zootecnia - Universidade Federal de Viçosa, Viçosa - Minas Gerais, Brasil. \\ ${ }^{3}$ Empresa Brasileira de Pesquisa Agropecuária - Embrapa Gado de Leite, Juiz de Fora - Minas Gerais, Brasil. \\ ${ }^{4}$ Departamento de Veterinária - Universidade Federal de Viçosa, Viçosa - Minas Gerais, Brasil.
}

\begin{abstract}
The main purpose of the present study was to identify for candidate genes related to ovulation in swines. To do so, it was investigated in ovarian follicular cells through quantitative real-time PCR the differential expression of the following genes: steroidogenic acute regulator (STAR), GATA-binding protein 4 (GATA), prostaglandin F2 $\alpha$ (PGF2 $\alpha$ ), progesterone receptor (P4R), follicle-stimulating hormone receptor (FSHR), and cytochrome P450 aromatase (CYP19). These genes encode hormone receptors (FSHR and P4R), hormone (PGF2 $\alpha$ ), steroidogenic proteins (STAR and CYP19) and transcription factor (GATA). Folicular cells were collected from sows with high and low number of piglets/litters during the follicular phase of the estrus cycle. There was difference in transcript abundance among low and high prolific sows for the STAR, GATA, PGF2 $\alpha$, P4R and CYP19 genes. For the FSHR gene, the fold change was not considered to be significantly different. Because in the present study only the transcript level of the above mentioned genes was analyzed, no inference can be made regarded to protein translation or activity. Therefore, gene sequence trials and other functional studies will be necessary to complement the present results, allowing a better understanding on biological complexity of these genes and their use as markers for prolificity in swines.
\end{abstract}

Key Words: candidate gene, litter size, ovulation rate, pig production, quantitative real-time PCR

\section{Expressão diferencial de genes em células foliculares de suínos}

\begin{abstract}
RESUMO - O objetivo neste trabalho foi identificar genes candidatos relacionados à ovulação em suínos. Para tanto, investigou-se a expressão diferencial dos genes STAR (steroidogenic acute regulator), GATA (GATA-binding protein 4), PGF2 $\alpha$ (prostaglandin F2 $\alpha$ ), P4R (progesterone receptor), FSHR (follicle-stimulating hormone receptor) e CYP19 (cytochrome P450 aromatase) em células foliculares ovarianas por meio de reação em cadeia da polimerase em tempo real (qRT-PCR) quantitativo em tempo real. Esses genes codificam para receptores hormonais (FSHR e P4R) hormônio (PGF2 $\alpha$ ), proteínas esteroidogênicas (STAR e CYP19) e fator de transcrição (GATA). As células foliculares foram coletadas durante a fase folicular do ciclo estral de porcas com alto e baixo número de leitões/leitegada. Houve diferença na abundância de transcritos entre porcas com alta e baixa prolificidade para os genes STAR, GATA, PGF2 $\alpha$, P4R and CYP19. Para o gene do FSHR, a alteração na abundância dos transcritos não foi significativamente diferente. Considerando que foi analisado somente o nível de transcrição desses genes mencionados, não se pode fazer inferências com relação à tradução ou atividade proteica. Portanto, ensaios de sequenciamento gênico e outras análises funcionais serão necessários para complementar esses achados e possibilitar melhor entendimento da complexidade biológica desses genes e seu uso como marcadores para prolificidade em suínos.
\end{abstract}

Palavras-chave: genes candidatos, ovulação, produção de suínos, PCR quantitativo em tempo real, tamanho de leitegada

\section{Introduction}

Swine is a high prolific animal, with a productivity of more than 20 piglets/sow/year (Johnson et al., 1999). An increase in reproductive efficiency has been observed over the last few decades, mainly as a result of genetic improvement of the herds. Among reproduction traits, reproductive performance, especially the number of piglets per litter, is fundamental for the success of pig production, where the increase in prolificity reduces production costs (Barbosa et al., 2008). However, this trait is sex-limited and shows low heritability of about 0.10 (Chen et al., 2003) and 0.22 (Torres-Filho et al., 2005), which represents a strong candidate for marker-assisted selection. Concerning to litter 
size, two factors are intimately related, ovulation rate and embryo survival or mortality. The ovulation rate refers to the number of oocytes released during the estrus period and it is one of the most important components of prolificity (Caetano et al., 2003). Because of this, the study of gene expression in ovarian follicular cells during different phases of the estrus cycle may have a high impact on the understanding of the reproductive biology of the swine, leading to the improvement of ovulation rates and consequently to an increase in litter size.

Molecular techniques used for the identification of genes or quantitative trait loci (QTL) for litter size are fundamental tools for the genetic understanding and improvement of reproductive traits when combined with traditional methods of selection. Concerning to this line of research, many strategies have been suggested, including the analysis of transcribed sequences for the characterization of gene function (Adams et al., 1991; Hatey et al., 1998). In this respect, the present study investigates candidate genes on the bases of their expression profiles. In order to reach this objective, the transcript abundance for the steroidogenic acute regulator gene (STAR), GATA binding protein 4 (GATA), prostaglandin $\mathrm{F}_{2 \alpha}\left(\mathrm{PGF}_{2 \alpha}\right)$, progesterone receptor (P4R), follicle-stimulating hormone receptor (FSHR) and cytochrome aromatase P450 (CYP19) were evaluated regarded to their differential expression profiles in follicular cells of high- and low-prolific sows using the technique of quantitative real-time PCR (qPCR).

\section{Material and Methods}

Follicular fluid samples were collected from commercial sow (Landrace $\mathrm{x}$ Large White $\times$ Pietrain) deriving which belongs to the Pig Breeding Program from the Departamento de Zootecnia of Universidade Federal de Viçosa. For sample collection, three high prolific and three low prolific sows were selected according to the number of piglets born alive during their first three parities, which is in average 12 for the high prolific group and 8.5 for the low prolific ones and because they belonged to a breeding programe, no more females were slaughtered (especially the high prolific ones), when this occurred, it was during the estrus cycle, however.

The statistical difference between the total number of piglets born (TNPB) and number of piglets born alive (NPBA) between both groups was calculated by Student t-test.

Follicular cells were collected immediately after slaughter from low and high prolific sows by puncture and aspiration of ovarian follicles during the estrus cycle
(10-20 $\mathrm{mm})$, using a disposable $5-\mathrm{mL}$ syringe with a needle. After aspiration, the follicular cells were pelleted by centrifugation and washed 2-3 times in $1 \mathrm{X}$ phosphatebuffered saline (PBS). The cells were resuspended in the same buffer and the number of cells in each sample was calculated by a Neubauer chamber counting. After counting, the cells were resuspended in RLT buffer (RNeasy Mini Kit, Qiagen, Valencia, CA, USA) supplemented with $\beta$-mercaptoethanol for extraction of total RNA.

Total RNA was extracted immediately after cell counting using the RNeasy Mini Kit (Qiagen) according to manufacturer recommendations. The samples were treated with DNase (RNase-Free DNase Set, Qiagen) as recommended by the manufacturer. The total RNA obtained was quantified by spectrophotometry and the $\mathrm{OD}_{260} / \mathrm{OD}_{280}$ ratio was calculated to evaluate RNA quality. RNA was stored at $-70^{\circ} \mathrm{C}$ until it was needed for use.

For cDNA synthesis, total RNA from animals of the same class was pooled, one pool from low prolific sows and the other from high prolific sows diluted at the same concentration. The material was pooled because of the search for general differences that could be assigned to high and low prolificity groups; individual results were not being investigated at that time. The first strand was synthesized from the total RNA template using the SuperScript III First-Strand Synthesis SuperMix Kit (Invitrogen, Carlsbad, CA, USA) according to manufacturer instructions. In both pools, cDNA concentration was determined by spectrophotometry before being stored at $-20^{\circ} \mathrm{C}$ until its use in the qPCR reactions.

The sequences were obtained from GenBank database (http://www.ncbi.nlm.nih.gov)(Table 1). The selected genes encode hormone receptors as a FSHR (Follicle-stimulating hormone receptor) and P4R (Prostaglandin receptor), hormone $\mathrm{PGF}_{2 \alpha}$ (Prostaglandin $\mathrm{F}_{2 \alpha}$ ), steroidogenic proteins STAR (Steroidogenic acute regulator) and CYP19 (Cytochrome P450) and transcription factor GATA (GATAbinding protein 4). According to Huggett et al. (2005), the GAPDH and $B$-actin genes are the ones most used for studies of gene expression and these genes were tested as endogenous control. The best efficiency of the reaction, showed by the standard curve, was showed by $\beta$-actin gene which was then used as a reference. The primers for the target genes and for the endogenous control ( $\beta$-actin) were designed using the PrimerQuest program (http:// www.idtdna.com) provided by Integrated DNA Technologies, Inc. (Coralville, IA, USA) (Table 1).

Quantitative real-time PCR was performed by using ABI PRISM ${ }^{\circledR} 7000$ Sequence Detection System (Applied 
Biosystems, Foster City, CA, USA). Relative quantification was performed using $\beta$-actin gene as endogenous control and the SYBR ${ }^{\circledR}$ Green Kit as detection system (Bio-Rad, Hercules, CA, USA). To estimate the efficiency of the reactions, different concentrations of primers and cDNA were tested for the target and the $\beta$-actin genes. Four cDNA concentrations (200,100, 10 and $1 \mathrm{ng})$ and three primer dilutions $(400,200$ and $100 \mathrm{nM})$ were tested. The best cDNA concentration for amplification was $200 \mathrm{ng}$ for the $\mathrm{PGF}_{2 \alpha}$ gene and $100 \mathrm{ng}$ for the other genes. The optimized primer concentrations were $200 \mathrm{nM}$ for the $\beta$-actin, STAR, CYP19 and FSHR genes and $400 \mathrm{nM}$ for the $\mathrm{PGF}_{2 \alpha}$, GATA and P4R genes. The efficiency of the reaction was calculated according to Livak \& Schmittgen (2001) and as published by Guimarães et al. (2007).

The reaction mixture contained $12.5 \mu \mathrm{L} 2 \mathrm{X}$ SYBR ${ }^{\circledR}$ Green Supermix (buffer, dNTPs, $\mathrm{MgCl}_{2}, \mathrm{SYBR}^{\circledR}$ Green and Taq DNA polymerase), primers and cDNA at the concentrations described above in a final volume of $25 \mu \mathrm{L}$. The reaction for each gene was carried out in individual tubes, and each sample was tested in replicate, for the target and the control genes. The following amplification conditions were used for all systems: $95^{\circ} \mathrm{C}$ for $3 \mathrm{~min}, 40$ cycles of denaturation at $95^{\circ} \mathrm{C}$ for 15 seconds and annealing and extension at $60^{\circ} \mathrm{C}$ for 60 seconds. After the 40 amplification cycles, all samples were submitted to the analysis of the dissociation curve to validate the absence of nonspecific products or primer dimers.

Transcript abundance for each target gene was evaluated by the formula $2^{-\Delta \mathrm{Ct}}$ (Livak \& Schmittgen, 2001), in which $\Delta \mathrm{C}_{\mathrm{t}}=\mathrm{C}_{\mathrm{t}}$ (target gene) $-\mathrm{C}_{\mathrm{t}}$ (control gene). The transcript abundance for target genes in follicular cells from low and high prolific pool samples were calculated based on the cycle threshold $\left(\mathrm{C}_{\mathrm{t}}\right)$. Differences in the expression of each gene were represented by the value of $2^{-\Delta \mathrm{Ct}}$ (arbitrary units). The fold changes are reported by the number of times that each gene was expressed in the low prolific pool than in the high prolific pool $(\mathrm{L} / \mathrm{H})$. Differences in expression of 1.5 times or higher between low and high prolific pools were considered differentially expressed.

Table 1 - Primer sets used for the amplification of each gene by real-time PCR

\begin{tabular}{|c|c|c|}
\hline Gene & GenBank accession number & Primer \\
\hline FSHR & $\mathrm{Nm} \_214386$ & $\begin{array}{l}\text { F-AGAACTTCCGCAGGGATGTCTTCA } \\
\text { R-TTGGATGAATGTTGTGGGCAGTGG }\end{array}$ \\
\hline P4R & S49016 & $\begin{array}{l}\text { F-AGCTCACAGCGTTTCTACCAGCTT } \\
\text { R-GGAAATTCAACACTCAGTGCCCG }\end{array}$ \\
\hline $\mathrm{PGF}_{2 \alpha}$ & Ab115763 & $\begin{array}{l}\text { F-TGACTACAAGAACTACGCCCTGCT } \\
\text { R-AGACAATGCCGTCCTCTGTGAAG }\end{array}$ \\
\hline STAR & NM_213755 & $\begin{array}{l}\text { F-TGTTCATCCAGCCAGGAGCTTCA } \\
\text { R-AACCAGAGTGGATGTTGCTGCAC }\end{array}$ \\
\hline CYP19 & S 80148 & $\begin{array}{l}\text { F-TGAGGCAACAGGAGTCCTAAATG } \\
\text { R - ATCTTGTGTTGCTTGATCTCAGGG }\end{array}$ \\
\hline GATA & $\mathrm{Nm} \_214293$ & $\begin{array}{l}\text { F-CAAATCGAAGACGTCAGCAGGTC } \\
\text { R-TCTGTCTTGATGGGACGCATCTCT }\end{array}$ \\
\hline$\beta$-Actin & AJ 312193 & $\begin{array}{l}\text { F-TCATGAAGATCCTCACGGAGCG } \\
\text { R-CGTAGCAGAGCTTCTCCTTGATGT }\end{array}$ \\
\hline
\end{tabular}

\section{Results and Discussion}

Mean TNPB and NPBA were 8.53 and 8.51 in the low prolific group, respectively, and 13.23 and 12.03 in the high prolific group, and the difference in these parameters was significant $(\mathrm{P}<0.01)$ between both groups (Table 2$)$.

The highest fold change was observed for the P4R gene, followed by the $\mathrm{PGF}_{2 \alpha}$, STAR, CYP19 and GATA genes. The FSHR gene showed a fold change indicating no differential expression according to this study (Table 3 ).

Petretto et al. (2006) stated that quantitative variation in gene expression levels acts as an intermediate phenotype situated between DNA sequence variation and more complex phenotypes. According to these authors, in most studies on expression of quantitative trait loci, the genomic thresholds for significance typically correspond to fold changes in gene expression greater than 1.5 - 2, which would limit the sensitivity to detect only cis-acting effects. In the present study, five out of six genes showed fold changes in transcript abundance. This finding might lead to the inclusion of these differentially expressed genes as strong candidates for further analysis concerning ovulation rate and prolificity in the swine.

In the present study, the gene displaying the greatest fold change (7.73) was P4R. The P4R protein mediates the physiological effects of progesterone, the main hormone 
produced by the corpus luteum. Progesterone is responsible for the implantation and maintenance of pregnancy in mammals, playing a key role in a series of coordinated steps comprising the implantation period of the embryo into the uterus (Ying et al., 2001). Peralta et al. (2005) analyzed the expression of progesterone receptors in the oviduct of sows during the follicular and luteal phase of the estrus cycle. The authors showed that the ovarian hormones estrogen and progesterone are respectively the main up and down physiological regulators of $\mathrm{P} 4 \mathrm{R}$ concentration and that post-translational control of the receptor levels seems to be more important than its transcriptional control, because according to those authors, mRNA levels did not differ significantly during the estrus cycle phases. In the present study, expression of the P4R gene, evaluated during the follicular phase, was higher in low prolific animals than in high prolific animals. In our study, low prolific sows presented high transcript levels for P4R during the follicular phase, so they might present lower concentration of progesterone, when compared to the high prolific ones, once this hormone is a down-regulator of its receptor. This hypothesis still needs to be tested, however.

The second greatest fold change (2.84) was observed for the gene that encodes prostaglandin $\mathrm{F}_{2 \alpha}\left(\mathrm{PGF}_{2 \alpha}\right)$. This hormone is responsible for luteolysis and the consequent onset of the follicular phase (McCracken et al., 1999). The

Table 2 - Mean phenotypic data obtained for the analyzed sows.

\begin{tabular}{lcc}
\hline Sow & $\begin{array}{c}\text { Total number of } \\
\text { pipipliget piglets born }\end{array}$ & $\begin{array}{c}\text { Number of } \\
\text { piglets born alive }\end{array}$ \\
\hline High prolific sows $_{1}$ & 13.2 & 12.2 \\
High prolific sows $_{2}$ & 14.0 & 12.4 \\
High prolific sows $_{3}$ & 12.5 & 11.5 \\
\hline Average standart $_{\text {deviation }}$ & $13.23(0,75)$ & $12.03(0.47)$ \\
\hline Low prolific sows $_{1}$ & 9.24 & 8.29 \\
Low prolific sows $_{2}$ & 8.0 & 8.0 \\
Low prolific sows $_{3}$ & 9.25 & 9.25 \\
\hline Average standart & & \\
deviation & $8.83(0.72)$ & $8.51(0.65)$ \\
\hline
\end{tabular}

Table 3 - Relative difference on expression of the genes STAR, GATA, PGF $2_{\alpha}$, P4R, FSHR e CYP19

\begin{tabular}{lc}
\hline Genes & $\begin{array}{c}\text { Relative difference } \\
\text { Low } \text { prolific }\end{array}$ sows/high prolific sows \\
\hline STAR & 2.32 \\
CYP19 & 2.30 \\
GATA & 2.31 \\
P4R & 7.73 \\
FSHR & 0.67 \\
PGF $_{2 \alpha}$ & 2.84 \\
\hline
\end{tabular}

activity of $\mathrm{PGF}_{2 \alpha}$ is mediated by its binding to a membrane receptor (FPr). At the end of the luteolytic phase, an increased number of FPr in the corpus luteum and a decreased concentration of $\mathrm{PGF}_{2 \alpha}$ are observed (McCracken et al., 1999). $\mathrm{PGF}_{2 \alpha}$ is particularly powerful in the interruption of pregnancy during its initial phase and this fact may influence litter size. Another fact showing that high $\mathrm{PGF}_{2 \alpha}$ concentrations may affect the maintenance of pregnancy in low prolific sows is that in pigs the corpus luteum is important for the maintenance of pregnancy and its removal has been shown to result in its interruption (Pilon et al., 1997). The fact that the transcript concentration for this hormone is higher in low prolificity sows may indicate a direct negative impact on prolificity of these animals. However, as we have conducted an experiment based on measure of transcript abundance, we can not infer on protein concentration and activity.

The STAR gene presented a fold change of 2.32. Its product encodes a protein that positively regulates the synthesis of steroid hormones during luteinization and steroidogenesis. The STAR protein participates in these events by facilitating the transport of cholesterol through the mitochondrial membrane, increasing its conversion into pregnenolone, a precursor of all steroids (Lavoie et al., 2004). In swines, the transcription of the STAR gene and the translation of its mRNA are positively regulated during postovulatory luteinization of follicular cells in the corpus luteum, a period directly related to the increased synthesis of progesterone. The same authors have indicated that the expression of STAR is positively regulated by the gonadotrophins $\mathrm{FSH}$ and $\mathrm{LH}$ and negatively regulated by $\mathrm{PGF}_{2 \alpha}$.

In the present study, STAR gene expression was analyzed in follicular phase and it was higher in low prolific sows, maybe because these animals start follicle luteinization earlier, leading to a reduction in the number of ovulated oocytes during estrus cycle and, consequently, to the number of piglets. The higher expression of the $\mathrm{PGF}_{2 \alpha}$ gene in low prolific sows confirms these results, with a reduction of gene expression, since this gene is required for luteolysis. However, since only the amount of mRNA in follicular cells was analyzed, it can be inferred that the message is being transcribed but we cannot do the same about what is happening on the post-transcriptional or post-translational levels.

The expression of the STAR gene is mediated by various transcription factors, including GATA-4-binding protein which is encoded by GATA gene (Lavoie et al., 2004). This gene (fold change of 2.31) belongs to a group of transcription factors responsible for the expression of 
many genes that control the differentiation processes of different cell types. According to Arceci et al. (1993), the expression of the GATA-4 gene is induced by retinoic acid and it is tissue-specific and being expressed in the heart, intestinal epithelium, primitive endoderm and gonads, where this gene plays a key role in the regulation of gene expression. GATA-4 gene is expressed before the differentiation of gonadal cells (Lavoie et al., 2004) and it is extremely important for this event.

In the present study, a higher expression of both STAR and GATA genes was observed in low prolific animals. A higher expression of these genes in low prolific animals would have been expected because GATA gene promotes the expression of the STAR gene, which is responsible for the follicle luteinization that may be interfering in the piglet number per litter. In contrast, no studies regarding the role of the GATA-4 gene in the regulation of the expression of the other genes analyzed are available in the literature. Further studies investigating its action at the pre- and posttranscriptional level are also necessary.

Another gene that plays a key role in steroidogenesis is CYP19 (fold change of 2.30), which encodes cytochrome $\mathrm{P} 450$ aromatase $\left(\mathrm{P} 450_{\text {aro }}\right)$, an enzyme responsible for the biosynthesis of estrogen (Robel, 1993). In a study on the expression of CYP19 in bovine granulosa cells, Vanselow et al. (2004) showed that its expression is associated to epigenetic mechanisms, especially DNA methylation. Many studies have shown different CYP19 gene polymorphisms in different human ethnic groups (Kvitko et al., 2004). The expression of this gene is positively regulated by estrogen, with higher expression levels being observed during the follicular phase of the estrus cycle. After the elevation of luteinizing hormone $(\mathrm{LH})$, it was observed a reduction in the level of estrogen and the CYP19 gene expression in preovulatory follicles (Komar et al., 2001).

The results concerned to the expression of the CYP19 gene may suggest the presence of higher estrogen concentrations in low prolific animals, since the product of this gene participates in the conversion of androgens to estrogens. Nevertheless, the lower expression of this gene in the high prolific sows may be due to the advanced stage of the analyzed follicles, preovulatory phase. However, for all genes analyzed in this study it is important to consider the genetic background of each animal, what is specially true for the CYP19 gene, because of the gene polymorphisms already identified in humans (Kvitko et al., 2004), and, because of the epigenetic mechanisms that can be associated to gene expression (Vanselow et al., 2004).

The FSHR gene was not differentially expressed according to fold change 0.67 . The main function of follicle- stimulating hormone (FSH) is to stimulate the growth of small and medium ovarian follicles (Mannaertz et al., 1994). This hormone is a follicular recruitment inducer and an apoptosis inhibitor of granulosa cells in swines, representing the main up- regulator of follicular grow and ovulation rate in these animals (Cárdenas \& Pope, 2002).

The amount of FSHR mRNA is relatively high during the initial phase of follicular development, but its concentration rapidly decreases when the follicles grow and reach ovulation, consequently this gene has a small influence on preovulatory follicles, a phase during which luteinizing hormone ( $\mathrm{LH}$ ) plays a central role (Cárdenas $\&$ Pope, 2002). It can be suggested that in the present study transcript levels of follicle-stimulating hormone were almost the same for both pools because of the advanced developmental stage of the analyzed follicles (follicular phase), with no significant difference in expression being observed. Analysis of expression of the follicle-stimulating hormonein other estrus phases, along with other ovulatory hormones, such as FSH and luteinizing hormone, may better evaluate the activity of this gene in low and high prolific sows.

In the present study, only the transcript abundance was evaluated for the candidate genes, and it would also be necessary to determine which type of control of gene expression predominates in all these different genetic systems and whether there are differences in genetic background, such as genomic variants and even epigenetic effects, as described for the CYP19 gene have to be considered. Moreover, it can not be forgotten that ovulation and prolificity are poligenic traits, in which many genes are involved in the phenotype. In this regard, the transcript abundance for regulatory hormones, such as GnRH and others have to be evaluated, as well as their interaction with other genes.

Litter size is not only a function of the ovulation rate; it is well established that an improved embryonic survival and a higher uterine capacity contribute to the phenotype (Foxcroft et al., 2006). Many studies have been done to better estimate the value of ovulation rate in litter size in swines and, according to Rosendo et al. (2007), ovulation rates and embryonic survival in the pre-implantation period increased the number of embryos that survived after the post-implantation period (day 25 to 30 ) and it will exceed the uterine capacity, resulting in uterine crowding and increased prenatal loss. This result typically shows that despite of the ovulation rate, many other factors are to be considered when the trait litter size is to be analyzed. In addition, litter size is not only a multi trait characteristic (ovulation rate, embryo survival, uterine capacity), it also 
shows low heritability, due to its large phenotypic variation mainly attributed to environmental factors such as nutrition and management conditions.

\section{Conclusions}

The expression of the STAR, GATA, PGF $2 \alpha$, P4R, CYP19 genes in follicular cells from sows also identifies expression differences in animals with different reproductive phenotypes. The higher relative gene expression of the STAR, GATA, PGF ${ }_{2 \alpha}, \mathrm{P} 4 \mathrm{R}, \mathrm{CYP} 19$ genes is observed in low prolific sows, and the FSHR gene does not reach the threshold difference established in this study. For the results presented in this study, we can state that the use of the qRT-PCR generates evidences for the selection of candidate genes related to ovulation in swines. In the near future, these genes will have their expression evaluated in different phases of the estrus cycle and will also be evaluated by SNP searching techniques in the aim of finding genomic markers that can be related to reproductive phenotypes. In addition, differences in the expression of these genes and of other related ones during the other phases of the reproductive cycle of sows should be analyzed in order to better understand reproductive phenotypes in pigs.

\section{References}

ADAMS, M.D.; KELLEY, J.M.; GOCAYNE, J.D. et al. Complementary DNA sequencing: expressed sequence tags and human genome project. Science, v.252, p.1651-1656, 1991.

ARCECI, R.J.; KING, A.A.J.; SIMON, M.C. et al. A retinoic acidinducible mouse GATA-4: GATA-binding in factor transcription expressed endodermally derived tissue and heart. Molecular and Cellular Biology, v.13, n.4, p.2235-2246, 1993.

BARBOSA, L.; LOPES P.S.; REGAZZI A.J. et al. Estimação de parâmetros genéticos em tamanho de leitegada de suínos utilizando análises de características múltiplas. Revista Brasileira de Zootecnia, v.37, n.11, p.1947-1952, 2008.

CAETANO, A.R.; JOHNSON, R.K.; POMP, D. Generation and sequence characterization of a normalized cDNA library from swine ovarian follicles. Mammalian Genome, v.14, p.65-70, 2003.

CÁRDENAS, H.; POPE, W.F. Control of ovulation rate in swine. Journal of Animal Science, v.80, p.36-46, 2002.

CHEN, P.; BAAS, T.J.; MABRY, J.W. et al. Genetic parameters and trends for litter traits in U.S. Yorkshire, Duroc, Hampshire, and Landrace pigs. Journal of Animal Science, v.81, p.46-53, 2003.

FOXCROFT, G.R.; DIXON, W.T.; NOVAK, S. et al. The biological basis for prenatal programming of postnatal performance in pigs. Journal of Animal Science, 84 (E-suppl), E105-E112, 2006.

GUIMARÃES, S.E.F; STAHL, C.H.; LONERGAN, S.M. et al. Myostatin promoter analysis and expression pattern in pigs. Livestock Science, v.112, p.143-150, 2007
HATEY, F.; TOSSER-KLOPP, G.; CLOUSCARD-MARTINATO, C. Expressed sequence tags for genes: a review. Genetic Selection Evolution, v.30, p.521-554, 1998.

JOHNSON, R.K.; NIELSEN, M.K.; CASEY, D.S. Responses in ovulation rate embryonal survival and litter traits in swine to 14 generations of selection to increase litter size. Journal of Animal Science, v.77, p.541-557, 1999.

KOMAR, C.M.; BERNDTSON, A.K.; EVANS, A.C.O. et al. Decline in circulating estradiol during the periovulatory period is correlated with decreases in estradiol and androgen, and in messenger RNA for p450 aromatase and p450 17alphahydroxylase, in bovine preovulatory follicles. Biology of Reproduction, v.64, p.1797-1805, 2001.

KVITKO K.; NUNES, J.C.D.E.B.; HUTZ, M.H. (TTTA)n polymorphism of CYP19 (aromatase gene) in Euro- and AfroBrazilians. Genetics and Molecular Biology, v.27, n.3, p.335-336, 2004

LAVOIE, H.A.; SINGH, D.; HUI, Y.Y. Concerted regulation of the porcine steroidogenicacute regulatory protein gene promoter activity by follicle-stimulating hormone and insulin-like growth factor I in granulosa cells involves GATA-4 and CCAAT/enhancer binding protein. Endocrinology, v. 145 , n.7, p.3122-3134, 2004.

LIVAK, K.J.; SCHMITTGEN, T.D. Analysis of relative gene expression data using real-time quantitative PCR and the 22DDCT method. Methods, v.25, p.402-408, 2001.

MANNAERTZ, B.; UILENBROCK, J.; SCHOT, P. et al Folliculogenesis in hypophysectomized rats after treatment with recombinant human follicle stimulating hormone. Biology of Reproduction, v.51, n.1, p.72-81, 1994

MCCRACKEN, J.A.; CUSTER E.E.; LAMSA J.C. Luteolysis: a neuroendocrine-mediated event. Physiological Reviews, v.79, n.2, p.263-324, 1999.

PERALTA, L.E.; OLARTE, M.; ARGAÑARAZ, M. et al Progesterone receptors: their localization, binding activity and expression in the pig oviduct during follicular and luteal phases. Domestic Animal Endocrinology, v.28, p.74-84, 2005.

PETRETTO, E.; MANGION, J.; DICKENS, N.J. et al. Heritability and tissue specificity of expression quantitative trait loci. PLoS Genetics, 2 (10 - e 172); p.1625-1633, 2006.

PILON, N.; DANEAU, I.; BRISSON, C. et al. Porcine and bovine steroidogenic acute regulatory protein $(\mathrm{StAR})$ gene expression during gestation. Endocrinology, v.38, n.3, p.1085-1091, 1997.

ROBEL P. Steroidogenesis: The enzymes and regulation of their genomic expression. In: THIBAULT C.; LEVASSEUR M.C.; HUNTER R.H.F. (Eds.) Reproduction in mammals and man. Paris: Elipses, 1993. p.135-142.

ROSENDO A.; DRUET T.; GOGUÉ J. et al. Direct responses to six generations of selection for ovulation rate of prenatal survival in Large White pigs. Journal of Animal Science, v.85, p.356$364,2007$.

TORRES-FILHO R.A.; TORRES R.A.; LOPES P.S. et al. Estimativas de parâmetros genéticos para características reprodutivas de suínos. Arquivo Brasileiro de Medicina Veterinária e Zootecnia, v.57, n.5, p.684-689, 2005

VANSELOW, J.; FÜRBASS, R.; REHBOCK, F. Cattle and sheep use different promoters to direct the expression of the aromatase cytochrome P450 encodinggene, Cyp19, during pregnancy. Domestic Animal Endocrinology, v.27, p.99-114, 2004 .

YING, C.; YANG, Y-C.; HONG, W-F. et al. Progesterone receptor gene expression in preimplantation pig embryos. Journal of Endocrinology, v.143, p.697-703, 2001 